\title{
CAMBRIDGE
}

\section{Outstanding Scholarship in Law}

Amnesty in the Age of Human Rights Accountability

Comparative and International Perspectives

Edited by Francesca Lessa and Leigh A. Payne

\$110.00: Hb: 978-1-107-02500-4: $456 \mathrm{pp}$ \$39.99: Pb: 978-1-107-61733-9

\section{Second Edition}

\section{An Introduction to Rights}

William A. Edmundson

Cambridge Introductions to

Philosophy and Law

S95.00: Hb: 978-1-107-01098-7: 200 pp. \$33.99: Pb: 978-1-107-64819-7

\section{Authoritarian Rule of Law} Legislation, Discourse and Legitimacy in Singapore Jothie Rajah

Cambridge Studies in Law and Society 599.00: Hb: 978-1-107-01241-7: 364 pp. \$29.99: Pb: 978-1-107-63416-9

\section{Contracts in the Real World}

Stories of Popular Contracts and Why They Matter

Lawrence A. Cunningham S99.00: Hb: 978-1-107-02007-8: 280 pp. \$29.99: Pb: $978-1-107-60746-0$

\section{Declaring War}

Congress, the President, and What the Constitution Does Not Say

\section{Brien Hallett}

\$95.00: Hb: 978-1-107-02692-6: 247 pp. S32.99: Pb: 978-1-107-60857-3

\section{Feminist Constitutionalism} Global Perspectives

Edited by Beverley Baines,

Daphne Barak-Erez, and Tsvi Kahana

\$110.00: Hb: 978-0-521-76157-4: 494 pp. S39.99: Pb: $978-0-521-13779-9$

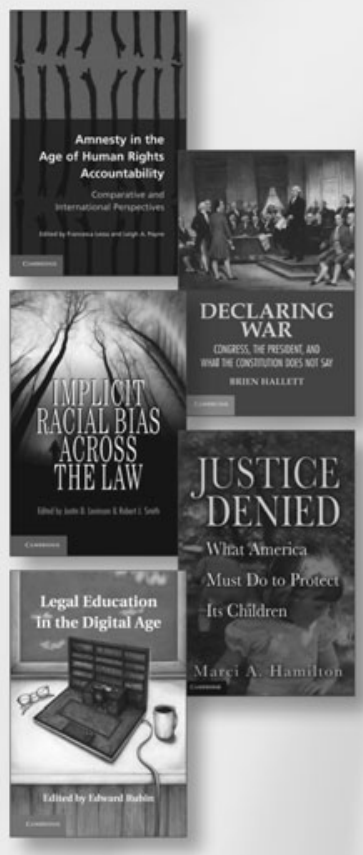

Student Edition

Hugo Grotius On the Law of War and Peace

Edited by Stephen C. Neff

S99.00: Hb: 978-0-521-19778-6: 546 pp. \$42.00: Pb: 978-0-521-12812-4

\section{Implicit Racial Bias}

\section{Across the Law}

Edited by Justin D. Levinson and Robert J. Smith

\$99.00: Hb: 978-1-107-01095-6: 284 pp. \$32.99: Pb: 978-1-107-64818-0

Indigenous Rights in the Age of the UN Declaration Edited by Elvira Pulitano S110.00: Hb: 978-1-107-02244-7: 368 pp.

\section{International Law,} US Power

The United States' Quest for Legal Security

Shirley V. Scott

\$99.00: Hb: 978-1-107-01672-9: 292 pp. \$30.00: Pb: 978-1-107-60259-5

Cambridge Studies in
Constitutional Law
Judging Social Rights
Jeff King
\$110.00: Hb: $978-1-107-00802-1: 398 \mathrm{pp}$.
\$45.00: Pb: $978-1-107-40032-0$
Proportionality
Constitutional Rights and
their Limitations
Aharon Barak
\$115.00: Hb: $978-1-107-00858-8: 638 \mathrm{pp}$.
\$55.00: Pb: $978-1-107-40119-8$

\section{Justice Denied}

What America Must Do to Protect its Children

Marci A. Hamilton

\$26.00: Hb: 978-0-521-88621-5: $168 \mathrm{pp}$. S18.99: Pb: 978-1-107-67312-0:

\section{Laughing at the Gods}

Great Judges and How They Made the Common Law

Allan C. Hutchinson

\$95.00: $\mathrm{Hb}$ : 978-1-107-01726-9: 328 pp. \$29.99: Pb: 978-1-107-66276-6

\section{Legal Education}

in the Digital Age

Edited by Edward Rubin

\$99.00: Hb: 978-1-107-01220-2: 270 pp.

Prices subject to change 


\section{CAMBRIDGE}

\section{Outstanding Scholarship in Law}

Loving vs. Virginia in a Post-Racial World

Rethinking Race, Sex, and Marriage Edited by

Kevin Noble Maillard and Rose Cuison Villazor \$99.00: Hb: 978-0-521-19858-5: $288 \mathrm{pp}$. S32.99: Pb: 978-0-521-14798-9

\section{Nepal in Transition}

From People's War to Fragile Peace Edited by

Sebastian von Einsiedel, David M. Malone, and Suman Pradhan

S99.00: Hb: 978-1-107-00567-9: 412 pp. S34.99: Pb: 978-1-107-66898-0

\section{Third Edition}

Principles of International Environmental Law

Philippe Sands

and Jacqueline Peel

Assisted by Adriana Fabra and Ruth MacKenzie

S150.00: Hb: 978-0-521-76959-4: $992 \mathrm{pp}$. \$85.00: $\mathrm{Pb}: 978-0-521-14093-5$

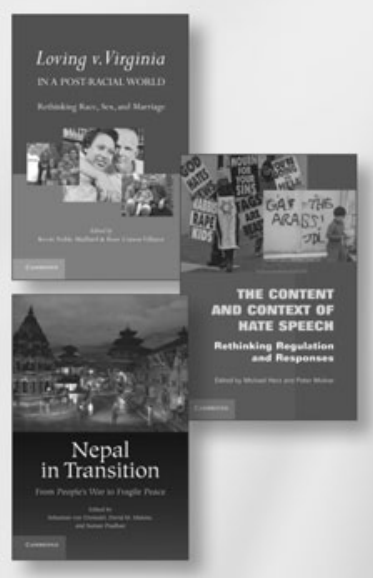

The Content and Context of Hate Speech

Rethinking Regulation and Responses

Edited by Michael Herz and Peter Molnar

\$99.00: Hb: 978-0-521-19109-8: 568 pp. \$44.99: $\mathrm{Pb}: 978-0-521-13836-9$

\section{Cambridge Companions to Law}

The Cambridge Companion to International Law

Edited by James Crawford and Martti Koskenniemi

S115.00: Hb: 978-0-521-19088-6: $484 \mathrm{pp}$. S45.00: Pb: 978-0-521-14308-0

The Cambridge Companion to Comparative Law

Edited by Mauro Bussani and Ugo Mattei

\$110.00: Hb: 978-0-521-89570-5: 432 pp. \$39.99: Pb: 978-0-521-72005-2
The Economic Dynamics of Law David M. Driesen \$99.00: Hb: 978-1-107-00485-6: 264 pp.

The European Union after the Treaty of Lisbon

Edited by Diamond Ashiagbor, Nicola Countouris, and loannis Lianos

\$110.00: Hb: 978-1-107-01757-3: 344 pp. \$44.99: Pb: 978-1-107-60324-0

The International Law of the Sea

Yoshifumi Tanaka

\$120.00: Hb: 978-1-107-00999-8: 504 pp. \$60.00: Pb: 978-0-521-27952-9

\section{Second Edition}

The Principles and Practice of International Commercial Arbitration

Margaret L. Moses

\$99.00: Hb: 978-1-107-00878-6: 378 pp. \$35.00: Pb: 978-1-107-40133-4

The Rule of Law and the Measure of Property Jeremy Waldron

The Hamlyn Lectures

\$50.00: Hb: 978-1-107-02446-5: $132 \mathrm{pp}$. S22.99: Pb: 978-1-107-65378-8

\section{Third Edition}

WTO Analytical Index 2 Volume Set Guide to WTO Law and Practice Legal Affairs Division, World Trade Organization \$410.00: 2 Hb books: 978-1-107-02525-7: $2,408 \mathrm{pp}$.

Prices subject to change 


\section{CAMBRIDGE}

\section{JOURNALS}

\section{Legal Theory}

\section{Editors}

Matthew D. Adler, University of Pennsylvania Law School, USA Larry Alexander, University of San Diego Law School, USA David O. Brink, University of California, San Diego, USA

Scott J. Shapiro, Yale Law School, USA

Legal Theory draws contributions not only from academic law, but from a wide range of related disciplines in the humanities and social sciences, including philosophy, political science, economics, history and sociology. Topics covered fall mainly into the broad categories of analytical and normative jurisprudence, doctrinal theory, policy analyses of legal doctrines and critical theories of law.

\section{Price information}

is available at: http://journals.cambridge.org/leg

\section{Free email alerts}

Keep up-to-date with new material - sign up at http://journals.cambridge.org/alerts

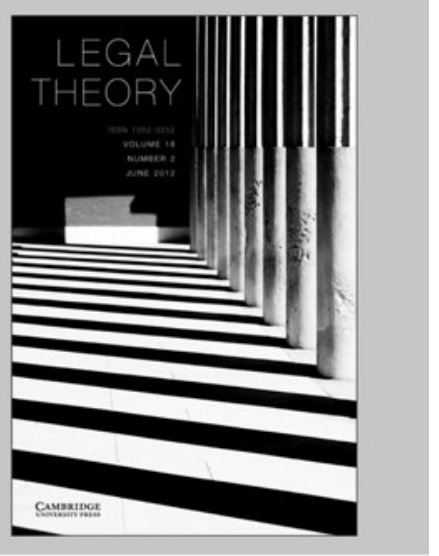

\section{Legal Theory}

is available online at:

http://journals.cambridge.org/leg

To subscribe contact Customer Services

\section{in Cambridge:}

Phone +44 (0) 1223326070

$\mathrm{Fax}+44(0) 1223325150$

Email journals@cambridge.org

in New York:

Phone +1 (845) 3537500

$\mathrm{Fax}+1(845) 3534141$

Email

subscriptions_newyork@cambridge.org 


\section{CAMBRIDGE JOURNALS}

\section{World Trade Review}

Editor

L. Alan Winters, University of Sussex, UK

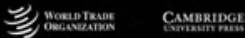

World Trade Review

The World Trade Review was established at the initiative of the Secretariat of the World Trade Organization (WTO) in close cooperation with Cambridge University Press. It is an independent journal - the Editor and all but one member of the Editorial Board are drawn from university faculties - that includes articles written from economic, legal, political and inter-disciplinary perspectives on issues of relevance to the multilateral trading system. Priority is given to papers that, along with being academically rigorous, are also accessible to government policy officials and the wider public. The journal also includes shorter articles seeking to rebut or challenge published papers.

is available online at:

http://journals.cambridge.org/wtr

To subscribe contact Customer Services

in Cambridge:

Phone +44 (0)1223 326070

$\mathrm{Fax}+44(0) 1223325150$

Email journals@cambridge.org

\section{in New York:}

Phone (845) 3537500

Fax (845) 3534141

Email

subscriptions_newyork@cambridge.org

\section{Free email alerts}

Keep up-to-date with new material - sign up at journals.cambridge.org/register 


\section{JOURNALS}

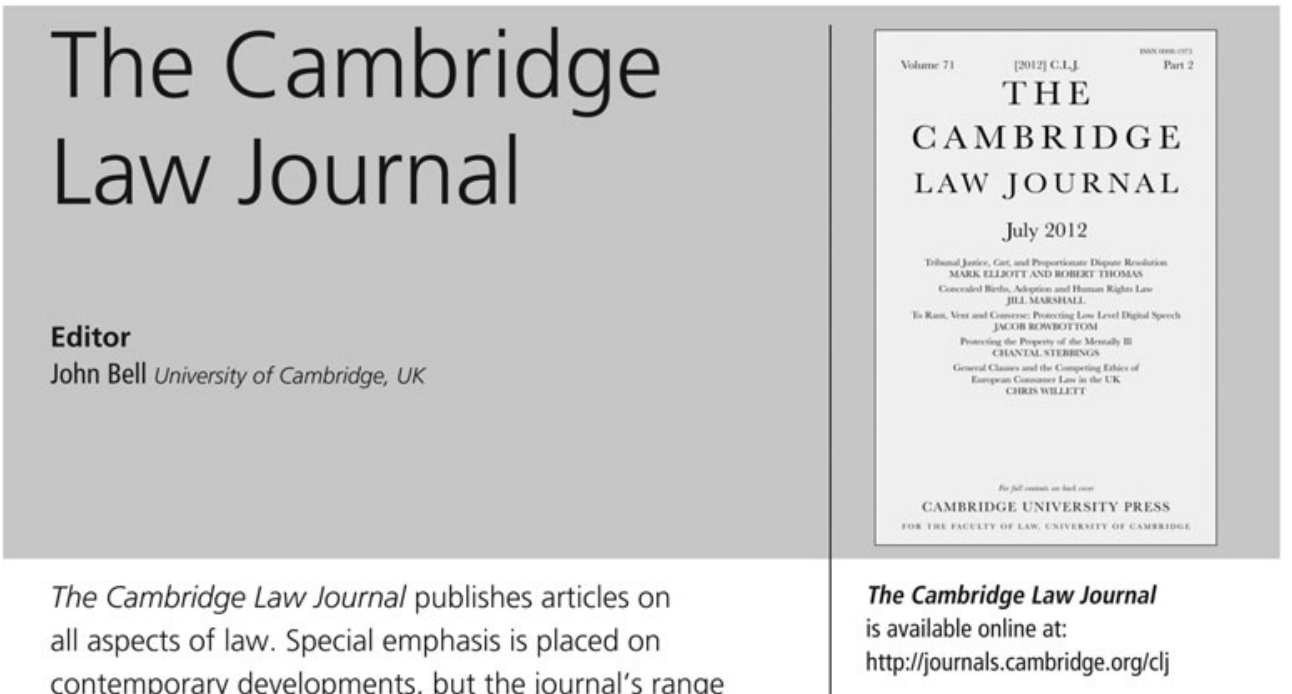

includes jurisprudence and legal history. An important feature of the journal is the Case and Comment section, in which members of the Cambridge Law Faculty and other distinguished contributors analyse recent judicial decisions, new legislation and current law reform proposals. The articles and case notes are designed to have the widest appeal to those interested in the law whether as practitioners, students, teachers, judges or administrators - and to provide an opportunity for them to keep abreast of new ideas and the progress of legal reform. Each issue also contains an extensive section of book reviews.

\section{To subscribe contact Customer Services}

\section{in Cambridge:}

Phone +44 (0) 1223326070

Fax $+44(0) 1223325150$

Email journals@cambridge.org

\section{in New York:}

Phone (845) 3537500

Fax (845) 3534141

Email

subscriptions_newyork@cambridge.org

\section{Free email alerts}

Keep up-to-date with new material - sign up at

journals.cambridge.org/register 


\section{CAmbridge}

\section{JOURNALS}

\section{European Constitutional Law Review}

Marketed and distributed for T.M.C. Asser Press

\section{Editors-in-Chief}

W. T. Eijsbouts, University of Amsterdam, The Netherlands

\section{Associate Editor-in-Chief}

Jan Herman Reestman, University of Amsterdam, The Netherlands

\section{Editor}

Leonard F. M. Besselink, University of Utrecht, The Netherlands Monica Claes, University of Tilburg, Netherlands

John W. Sap, University of Amsterdam, The Netherlands

The European Constitutional Law Review (EuConst), is a platform for advancing the study of European constitutional law, its history and evolution. Its scope is European law and constitutional law, history and theory, comparative law and jurisprudence. Published triannually, it contains articles on doctrine, scholarship and history, plus case law and book reviews. EuConst is addressed at academics, professionals, politicians and others involved or interested in European constitutional developments. Its Editorial Advisory Board is composed of eminent members in the field of constitutional studies from across the Continent in its new EU format.
For free online content visit: http://journals.cambridge.org

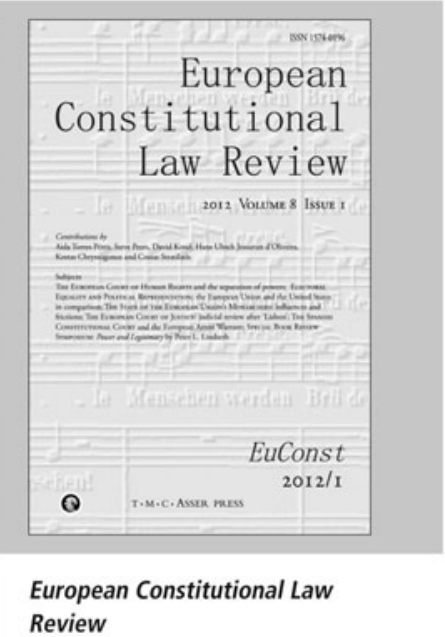

is available online at: http://journals.cambridge.org/ecl

\section{To subscribe contact Customer Services}

\section{in Cambridge:}

Phone +44(0)1223 326070

$\mathrm{Fax}+44(0) 1223325150$

Email journals@cambidge.org

\section{in New York:}

Phone (845) 3537500

Fax (845) 3534141

Email

subscriptions_newyork@cambridge.org

\section{Free email alerts}

Keep up-to-date with new material - sign up at

journals.cambridge.org/ecl-alerts 


\section{CAMBRIDGE JDURNALS}

\section{Celebrating 25 Years in 2012}

\section{Leiden Journal of International Law}

Published for The Foundation of the Leiden Journal of International Law

\section{Editors-in-Chief}

Larissa van den Herik, Leiden University, The Netherlands Jean D'Aspremont, University of Amsterdam, The Netherlands
Leiden Journal of International Law

Leiden Journal of International

Law is available online at: http://journals.cambridge.org/ljil

To subscribe contact Customer Services

in Cambridge:

Phone +44 (0)1223 326070

$\mathrm{Fax}+44(0) 1223325150$

Email journals@cambridge.org

in New York:

Phone (845) 3537500

Fax (845) 3534141

Email

subscriptions_newyork@cambridge.org

\section{Free email alerts}

Keep up-to-date with new material - sign up at journals.cambridge.org/ljl-alerts 


\section{Instructions for contributors}

The International Journal of Law in Context is the companion journal to the Law in Context book series. It is a forum for interdisciplinary legal studies and offers intellectual space for ground-breaking critical research. It publishes contextual work about law and its relationship with other disciplines including but not limited to science, literature, humanities, philosophy, sociology, psychology, ethics, history and geography. The journal explores and expands the boundaries of law and legal studies.

\section{Submissions}

Articles submitted for publication should be sent to: Professor Michael Freeman, Faculty of Laws, University College London, Bentham House, Endsleigh Gardens, London, WCIH oEG UK

Email uctlmdf@ucl.ac.uk

Contributors are responsible for obtaining permission to reproduce any materials, including photographs and illustrations, for which they do not hold copyright and for ensuring that the appropriate acknowledgements are included in the manuscript.

All contributions in the journal are peer-reviewed. Upon acceptance of a paper, the authors will be asked to assign copyright to Cambridge University Press.

Books for review should be sent to:

Helen Reece, Department of Law, London School of Economics, Houghton Street, London WC2A $2 \mathrm{AE}$ UK Email h.reece@lse.ac.uk

Manuscript preparation

I Articles should be written in English. They should not have been published already, nor should they be under consideration elsewhere.

2 Each article should be accompanied by the following information on a separate sheet

- the title of the article

- the author's name, affiliation and institutional address, together with an email address, and telephone and fax numbers

- an abstract of I00-I50 words

- articles should be between 6,000 and 20,000 words, including notes.

3 Articles must be word processed and double-spaced. A4 or American Quarts paper should be used.

Three copies should be submitted.

4 Any articles containing material subject to copyright restrictions other than those owned or controlled by the contributor must be accompanied by appropriate permissions from the relevant copyright holder(s).
5 For referencing use the Harvard-style system. Surname and date should be cited in the text, with a page reference where relevant, together with an alphabetically ordered end list. Use the following style in the Reference List

Dworkin, Ronald (2000) Sovereign Virtue. Cambridge, Mass: Harvard University Press

Daniels. Cynthia R. (I999) 'Fathers, Mothers and Fetal Harm: Rethinking Gender Difference and Reproductive Responsibility' in Lynn M. Morgan and Meredith W. Michaels (eds) Fetal Subjects, Feminist Positions. Philadelphia: University of Pennsylvania Press, 83-98

Macaulay, Stewart (2003) 'The Real and the Paper Deal: Empirical Pictures of Relationships, Complexity and the Urge for Transplant Rules', Modern Law Review 66: 44-79

Citations in new editions of previously published works should include the date of the original edition and the new edition in the text and in the reference list e.g. Mill (I859/I989)

6 Footnotes should be used rather than end notes. Each time a case is referred to in the text, the case report reference should be set out in the footnote. One report reference is sufficient.

References to UK statutes should be made as follows

Matrimonial Causes Act I973, S.25

Statutory instruments should be referred to by name and date (i.e. short title) followed by the number e.g. Local Authorities (Smallholdings) Order 1974, SI I974/396

7 Tables should be presented on separate sheets at the end of the article and should have short descriptive titles. Figures should be clearly numbered and should have explanatory captions. The author must indicate where Tables and Figures should be placed in the text.

Proofs

Only essential typographical or factual errors may be changed at proof stage. Resist the temptation to revise or add to the text. The publisher reserves the right to charge authors for correction of non-typographical errors.

Offprints

No paper offprints are provided, but the corresponding author will be sent the pdf of the published article. Print offprints may be purchased at extra cost at proof stage. 


\section{International Journal of Law in Context}

\section{A Global Forum for Interdisciplinary Legal Studies}

CONTENTS

\section{Articles}

337-353 The vulnerable subject of negligence law

Carl F. Stychin

354-393 The formation of a European constitution: an approach from historical-political sociology

Chris Thornhill

394-4I 2 Virtual walls? The law of pseudo-public spaces Daithí Mac Síthigh

4I3-430 An intentional basis for corporate personality

Anthony Amatrudo

Review essay

43I-446 Visual justice

Leslie J. Moran

Corrigendum

447 Hopeless cases: race, racism and the 'vexatious litigant'

Didi Herman

Cambridge Journals Online

For further information about this journal please go to the journal website at: journals.cambridge.org/ijc

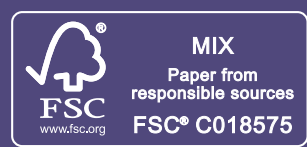

\section{CAMBRIDGE UNIVERSITY PRESS}

